\title{
Reconceptualizing Vagueness: Legal Rules and Social Orders
}

\author{
Robert C. Post $\dagger$
}

"'[I]ndefiniteness' is not a quantitative concept."

The void for vagueness doctrine is traditionally understood as concerned with the capacity of legal rules to control conduct. The doctrine underwrites the clarity of the law's distinction between acceptable and forbidden behavior, so as both to guide the actions of citizens and to restrict the discretion of government officials. In the words of a recent Supreme Court decision, the doctrine, "[a]s generally stated, ... requires that a penal statute define the criminal offense with sufficient definiteness that ordinary people can understand what conduct is prohibited and in a manner that does not encourage arbitrary and discriminatory enforcenent.".2

The traditional account of void for vagueness doctrine thus focuses on the nature of legal rules. It invites us to perceive the question of vagueness as a continuous variable, as "a matter of degree,"3 so that one can speak of a rule as having more or less "definiteness" and therefore as exercising more or less control over government caprice and citizen conduct. For this reason an unconstitutionally vague statute can be rewritten so as to be clearer or more precise. Hence vagueness analysis is said to "address itself to the form of regulation, without reference to the ultimate amenability to regulation of its subject."

I do not mean to deny that this traditional image of vagueness doctrine is often valid and appropriate. But I wish in this Essay to call attention to a significant class of cases in which this image is inaccurate and misleading. In these cases courts do not use vagueness doctrine to focus on the isolated properties of legal rules, but rather to analyze the relationship between legal rules and forms of social order. My hypothesis is that different kinds of legal rules presuppose and instantiate different forms of social order, and that vagueness doctrine is frequently employed to distinguish among the

Copyright (C) 1994 Robert C. Post.

$\dagger$ Professor of Law, Boalt Hall School of Law, University of California, Berkeley. A.B. 1969, Harvard College; J.D. 1977, Yale Law School; Ph.D. 1980, Harvard University.

1. Winters v. New York, 333 U.S. 507, 524 (1948) (Frankfurter, J., dissenting).

2. Kolender v. Lawson, 461 U.S. 352, 357 (1983).

3. Pregent v. New Hampshire Dep't of Employment Sec., 361 F. Supp. 782, 798 (D.N.H. 1973), vacated, 417 U.S. 903 (1974).

4. Note, The Void-for-Vagueness Doctrine in the Supreme Court, 109 U. PA. L. REv. 67, 113 (1960) (emphasis omitted). 
forms of social order that may appropriately be enforced by law in particular circumstances. Thus an unconstitutionally vague statute sometimes cannot simply be rewritten to be clearer or more precise; it must instead be refashioned to reflect entirely alternative models of social life.

\section{I \\ VAGUENESS AND DisCRETION}

We can perhaps achieve a better fix on the concept of vagueness by comparing it to its fraternal twin, the concept of "discretion." In conventional legal parlance the doctrine of undue discretion is most often used when laws are addressed to official decisionmakers, whereas vagueness doctrine is typically used when legal rules directly constrain the conduct of ordinary citizens. Because officials are presumed to act only as authorized by law, while citizens are presumed to act freely except as restricted by law, the doctrine of discretion is far more developed than that of vagueness.

We speak of officials as having discretion "in at least three distinct dimensions":.5 with respect to the process of their decisionmaking; ${ }^{6}$ with respect to the review of their decisions by third parties; ${ }^{7}$ and with respect to the specificity of the rules which constrain their decisions. These three dimensions reflect the care we take to fuse official action with law. ${ }^{8}$ Private citizens, however, are not fundamentally empowered by law; they are merely required to obey its commands. For this reason the first two dimensions of discretion are largely irrelevant to vagueness doctrine, which focuses instead chiefly on the quality of the rules by which we constrain citizen behavior.

It is useful to compare discretion and vagueness with respect to the third dimension of discretion. Consider the following three decision rules ${ }^{9}$ addressed to the traffic police:

1. Regulate traffic as you see fit.

2. Regulate traffic so as to avoid congestion.

5. For a full analysis, see Robert C. Post, The Management of Speech: Discrefion and Rights, 1984 Sup. CT. REv. 169, 206-21.

6. Hence we speak of the discretion of an official decisionmaker as dependent upon the particular procedures she must use. A decisionmaker has more discretion if she need not sct forth findings of fact; she has less discretion if she must announce justifications for her decisions; she has less discretion if her decisions must be based upon properly admitted evidence; and so forth.

7. Hence we speak of the discretion of an official decisionmaker as dependent upon the standards by which her decisions will be reviewed. She has less discretion if her decisions will be reviewed under a standard of independent review; she has more discretion if the standard of review is "abuse of discretion"; and so forth.

8. To adopt a phrase Chief Justice Marshall once used to describe courts, government officials may be said to be "the mere instruments of the law." Osborn v. President of the Bank of the United States, 22 U.S. ( 9 Wheat.) 738, 866 (1824).

9. On the distinction between decision rules, which are addressed to officials, and conduct rules, whicb are addressed to the general public, see Meir Dan-Cohen, Decision Rules and Conduct Rules: On Acoustic Separation in Criminal Law, 97 HARv. L. Rev. 625 (1984). 
3. Regulate traffic so that it alternates between two minutes' movement in a north/south direction and three minutes' movement in an east/west direction.

These rules appear arrayed on a spectrum of decreasing discretion. ${ }^{10}$ Rule 1 provides the police with no guidance; Rule 2 requires the police to exercise judgment, while Rule 3 imposes upon the police a mimisterial task that leaves no room for discretion at all. If confining official discretion were a legal concern, Rule 1 would be most obviously suspect, while Rule 2 would present a closer, more debatable question. Rule 3 would not be problematic.

Now compare decision Rules 1-3 with three parallel conduct rules addressed to the general public:

4. Cross the intersection whenever you see fit.

5. Cross the intersection only when it is safe.

6. Cross the intersection only when the light is green; do not enter the intersection when the light is red.

Rules 4-6 are arrayed along an analogous spectrum to Rules 1-3. Rule 4 offers the citizen virtually unguided discretion; Rule 5 requires the citizen to exercise judgment, while Rule 6 inuposes on the citizen a clear, ministerial duty. Rule 3 and Rule 6 are analogous in that neither raises a question of discretion or vagueness. But there is an interesting lack of symmetry between Rule 4 and Rule 1 . If Rule 1 is problematic because of its unbounded grant of discretion, Rule 4 poses no issue at all of unconstitutional vagueness. This is because Rule 4 merely empowers citizens without erecting restraints whose violation might subject them to legal sanction. We could, however, reformulate Rule 4 in this way:

4a. Do not cross the intersection unless the closest policeman is feeling benevolent toward you.

Unlike Rule 4, which authorizes citizen action, Rule 4a subjects citizens to the constraints of an uncertain and unknowable legal standard. It thus raises classic issues of vagueness, in part because of the obscure location of legal restraint, and in part because of the large discretion ceded to officials in determining that location. If one thinks of vagueness as a continuous variable, as a matter of more or less clarity, Rule $4 a$ represents a paradigmatic case. ${ }^{11}$

10. See Daniel J. Gifford, Discretionary Decisionmaking in the Regulatory Agencies: A Conceptual Framework, 57 S. CAL. L. Rev. 101, 102 (1983).

11. Why the vagueness cntailed by Rule 4 a should be conceived in terms of a continuous variable is actually quite puzzling. It is probably because the official discretion established by Rule $4 \mathrm{a}$ is ordinarily conceptualized in terms of a spatial metaphor, as for example in Ronald Dworkin's image of "the hole in a doughnut, ... an area left open by a surrounding belt of restriction." RoNALD DwORKIN, TAKING Rights SERIOUSLy 31 (1977). The hole represents a physical volume that can be greater or smaller. For a different spatial metaphor, see Kenneth C. Davis. Discretionary Justice: A Preliminary InQuiRy 3 (1969) ("Where law ends, discretion begins . . . ."). 
In this Essay, I shall not address vagueness questions of the kind raised by Rule $4 \mathrm{a}$. Instead I will consider the application of vagueness doctrine to laws like Rule 5, which impose upon citizens the obligation to exercise judgment. This obligation necessarily mirrors that established by laws like Rule 2, which require officials to exercise judgment as to the parameters of permissible conduct. My exact claim is that in the context of laws like Rule 5 , vagueness doctrine often functions to distinguish between acceptable and unacceptable kinds of judgments.

\section{II \\ VAGUENESS AND JUDGMENT}

The law commonly expresses itself through rules whose applications turn on the exercise of judgment. Judgments interpret and apply social standards or norms. This is what fundamentally distinguishes Rule 5 from Rule 4a, or Rule 2 from Rule 1 . Compliance with Rule 4 a or Rule 1 does not require the citizen or official to attempt to interpret and apply shared social standards. Instead these rules place the force of law entirely at the service of merely private preferences, ${ }^{12}$ personal likes or dislikes that make no claim to public validity. That is why courts have viewed laws like Rule $4 \mathrm{a}$ and Rule 1 as especially suspect from a constitutional point of view. ${ }^{13}$

The distinction between preferences and judgments can be illuminated by comparing

Proposition 1: "I like strawberry ice cream." with

Proposition 2: "Homer is a great poet."

Proposition 1 is a preference. It makes little difference whether we view it as expressive of personal desire or instead as a factual characterization of the subjective state of mind of the speaker. In either case Proposition 1 makes no claim upon its addressee. In contrast Proposition 2, which is a judgment, invites its addressee to participate in a common process of evaluation. This process can proceed only on the presupposition that both speaker and addressee are committed to interpreting and applying shared and intersubjective standards of aesthetic quality. ${ }^{14}$ Such standards do not

12. On the distinction between judgments and preferences, see Robert C. Post, The Constitutional Concept of Public Discourse: Outrageous Opinion, Democratic Deliberation, and Hustler Magazine v. Falwell, 103 HaRv. L. Rev. 601, 624-26, 652-61 (1990).

13. See generally Cass R. Sunstein, Naked Preferences and the Constitution, 84 Colum. L. Rev. 1689 (1984) (arguing that many constitutional provisions are aimed at preventing the implementation of "naked preferences").

14. These standards have a peculiar and ambiguous status. They are in some sense independent of both speaker and addressee because they exist in a common, cultural space, and yct they are also necessarily responsive to the ways in which they are perceived and applied by those who use them. The status of the standards might thus be conceptualized as analogous to rules of grammar or linguistic meaning, which are both independent of the expression of partieular speakers and yet dependent upon the expression of competent speakers generally. 
exist in a vacuum; they must be situated and maintained within real and specific social structures. In the case of Proposition 2, such structures would no doubt include authoritative educational and cultural institutions.

Standards situated and maintained by social structures are always the standards of a particular social group or class or institution. It follows that the validity of a judgment is always relative to the social group which is the source of the standards by which the validity of the judgment is to be assessed. As Ronald Beiner has observed, "[T]here must be underlying grounds of judgment which human beings, qua members of a judging community, share, and which serve to unite in communication even those who disagree (and who may disagree radically). . . Judgment implies a community that supplies common grounds or criteria by which one attempts to decide." 15 The necessary implication is that "we require a definition of community in order to know how the judgment shall proceed."16

There are many reasons why rules requiring judgments may be unconstitutional, but there are at least two that have particular pertinence to vagueness doctrine. First, the enforcement of a rule may require the exercise of a judgment that refers for its validation to social standards that are insufficiently dense and textured to sustain the bona fide exercise of judgment. Second, the enforcement of a rule may require the exercise of a judgment that refers for its validation to social standards that constitutionally .ought not to be applied to the social domain that is regulated by the rule.

Kolender v. Lawson ${ }^{17}$ offers a good example of the first kind of difficulty. At issue in Kolender was a California statute requiring those "who loiter or wander on the streets to provide a 'credible and reliable' identification" when requested to do so by a police officer. ${ }^{18}$ The Court concluded that the requirement of proffering "credible and reliable" identification was unconstitutionally vague because "the statute vests virtually complete discretion in the hands of the police to determine whether the suspect has satisfied the statute and must be permitted to go on his way." 19

The Court's decision was premised on its perception that there were no shared understandings that gave meaning or content to the standard of "credible and reliable identification." The standard referenced neither known community norms nor established bureaucratic practices. Thus the statute purported to require the exercise of judgment, yet the social prerequisites necessary for a true exercise of judgment were in fact absent. Application of the statute could consequently reflect only personal preference, only pleasure or "'displeasure," "20 only "'the whim of any police

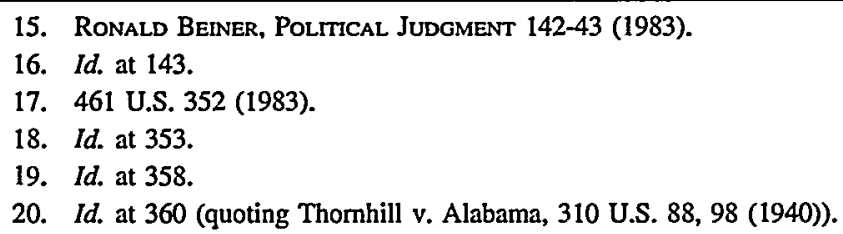


officer." "21 Although the statute was cast in a linguistic form that appeared to impose the obligation of judgment, the nature of the social order in which the statute was actually embedded rendered this form deceptive. Those applying the statute could only exercise a kind of faux judgment. Written in language that was superficially similar to Rule 5 , the statute at issue in Kolender actually functioned like Rule 4a.

In this Essay I shall not focus on cases of faux judgment, like Kolender, but rather on cases in which the law calls for the exercise of real judgment. I shall explore how courts use vagueness doctrine constitutionally to discriminate among such judgments. My hypothesis is that this use of vagueness doctrine ultimately entails the question of whether the norms necessary for the validation of the relevant judgment are constitutionally appropriate for the social domain regulated by the legal rule.

A good example of this kind of case is Papachristou v. City of Jacksonville, ${ }^{22}$ in which the Court invalidated an anti-vagrancy ordinance of the city of Jacksonville, Florida. The ordinance consisted of a long catalogue of peccadillos; it was a transparent attempt by bourgeois Jacksonville society to identify and outlaw the behavior of those who did not share their self-disciplined, productive, middle-class virtues. ${ }^{23}$ The Court invalidated the ordinance as "void for vagueness," 24 characterizing it as a vehicle for " "whim" "25 and "unfettered discretion."26

This characterization of the ordinance, however, was plainly inaccurate. For, as the Court recognized, the fundamental thrust of the ordinance was to identify social "undesirables"27 and to subject them to police control. With respect to this crucial purpose the ordinance was anything but standardless. It is clear that competent members of upstanding Jacksonville society could with confidence determine who was targeted by the ordinance and who was not. The ordinance was in fact designed to maintain the boundaries of proper Jacksonville society and thus to establish for that com-

21. Id. at 358 (quoting Shuttlesworth v. City of Birmingham, 382 U.S. 87,90 (1965)).

22. 405 U.S. 156 (1972).

23. The relevant law, Jacksonville, Fla., Ordinance Code § 26-57, provided:

Rogues and vagabonds, or dissolute persons who go about begging, common gamblers, persons who use juggling or unlawful games or plays, common drunkards, common night walkers, thieves, pilferers or pickpockets, traders in stolen property, lewd, wanton and laseivious persons, keepers of gambling places, common railers and brav/lers, persons wandering or strolling around from place to place without any lawful purpose or object, habitual loafers, disorderly persons, persons neglecting all lawful business and habitually spending their time by frequenting houses of ill fame, gaming houses, or places where alcoholic beverages are sold or served, persons able to work but habitually living upon the eamings of their wives or minor children shall be deemed vagrants and, upon conviction in the Municipal Court shall be punished as provided for Class D offenses.

Id. at $156-57 \mathrm{n} .1$.
24. Id. at 162 .
25. Id. at 170 (quoting Shuttlesworth, 382 U.S. at 90).
26. Id. at 168 .
27. Id. at 171 . 
munity "its distinctive shape, its unique identity." ${ }^{28}$ The judgments required by the ordinance were sustained by the dense network of norms that defined middle-class rectitude and discipline.

The Court signaled its understanding of this aspect of the ordinance by noting that what was most deeply at stake in the case was the fact that "poor people, nonconformists, dissenters, [and] idlers ... may be required to comport themselves according to the hifestyle deemed appropriate by the Jacksonville police and the courts." 29 The Court knew full well that the ordinance would not be applied to the local minister who loitered with his parishioners after the conclusion of services, or to the local banker who took a leisurely stroll home after a long night's work.

The ordinance at issue in Papachristou, therefore, did not function like Rule 4a. The constitutional question posed by the ordinance was not whether the exercise of judgment was possible, but rather whether the exercise of a certain kind of judgment was permissible. The Court could have argued that it was constitutionally forbidden to use judgments to impose "lifestyle" norms on unwilling segments of the population, and the Court in fact trembled at the brink of just such a substantive due process analysis:

Walkers and strollers and wanderers may be going to or coming from a burglary. Loafers or loiterers may be "casing" a place for a holdup. Letting one's wife support him is an intra-family matter, and normally of no concern to the police. Yet it may, of course, be the setting for numerous crimes.

The difficulty is that these activities are historically part of the amenities of life as we have known them. They are not mentioned in the Constitution or in the Bill of Rights. These unwritten amenities have been in part responsible for giving our people the feeling of independence and self-confidence, the feeling of creativity. These amenities have dignified the right of dissent and have honored the right to be nonconformists and the right to defy submissiveness. They have encouraged lives of high spirits rather than hushed, suffocating silence.

They are embedded in Walt Whitman's writings, especially in his "Song of the Open Road." They are reflected, too, in the spirit of Vachel Lindsay's "I Want to Go Wandering," and by Henry D. Thoreau. ${ }^{30}$

The difficulty with this reasoning, however, is that the law commonly inflicts social norms on unwilling populations. Most regulations of vice are of this nature. Despite the brave acknowledgment of Whitman and Thoreau, therefore, it would not have been easy for the Court to determine when legal enforcement of social norms would be so productive of "huslied,

28. Kai T. Erikson, Wayward Purttans: A Study in the Soctology of Deviance 11 (1960).

29. Papachristou, 405 U.S. at 170.

30. Id. at 164 . 
suffocating silence" as to be unconstitutional. Perhaps for this reason the Court never developed this line of argument.

It is thus tempting to read the Court's resort to vagueness doctrine as simply a cover for its embarrassing inability to develop a sustained substantive analysis. But that would be too harsh. It is possible to offer a more positive account of vagueness doctrine's contribution to Papachristou if one focuses on the opinion's concern to prevent "arbitrary ... arrests and convictions."31 Arbitrary arrests may follow a perfectly consistent and predictable internal logic; they may be neither random nor based upon personal preferences. Yet such arrests may nevertheless be constitutionally arbitrary if they answer to a logic that is legally irrelevant or unacceptable.

We can interpret Papachristou, therefore, as holding that the norms of middle-class virtue are not a constitutionally acceptable basis for ordering the relationship between police and citizen. The case, in effect, decides that it is constitutionally arbitrary and improper to use compliance with bourgeois morals as a trigger for police control. Hence the opinion's ringing conclusion:

[T] ]he rule of law implies equality and justice in its application. Vagrancy laws of the Jacksonville type teach that the scales of justice are so tipped that even-handed administration of the law is not possible. The rule of law, evenly applied to minorities as well as majorities, to the poor as well as the rich, is the great mucilage that holds society together. ${ }^{32}$

On this reading, vagueness doctrine functions in Papachristou to oversee the kinds of judgments that can be made by government officials within the domain of police-citizen interactions. The case strongly suggests that such judgments are valid only if justified by reference to the kinds of impersonal norms described by Max Weber as rational and bureaucratic. ${ }^{33}$ Judgments that by contrast appeal for validation to middle-class mores are deemed unconstitutionally arbitrary, vague, and unenforceable. Although vagueness doctrine enters this reasoning as a bare summary conclusion, as a bald determination that certain judgments are inappropriate, it is nevertheless fair to read the doctrine in Papachristou as clearly distinguishing between circumstances where the rule of law can constitutionally reflect and incorporate community norms ${ }^{34}$ and circumstances where the rule of law is expected to repel and override such norms.

31. Id. at 162 .

32. Id. at 171 .

33. See Max Weber, Economy and Society: An Outzine of INTERPretive Sociolocy 223-26 (Guenther Roth \& Claus Wittich eds. \& Ephraim Fischoff et al. trans., 1978).

34. For examples of the law functioning in this way, see Rohert C. Post, The Social Foundations of Privacy: Community and Self in the Common Law Tort, 77 CaLIF. L. Rev. 957 (1989); Paul Bohannan, The Differing Realms of the Law, AM. ANTHRopologist, Dec. 1965 (part 2), at 33 (special issue on Ethnography and Law, Laura Nader ed.). 
III

\section{VAGUENESS AND THE MARKET}

The tension between the rule of law and community mores is sharpest where legal standards serve policies that run contrary to ordinary understandings. The best example in contemporary constitutional law is the area of freedom of speech, where the First Amendment can be understood as self-consciously functioning to suspend community norms. ${ }^{35}$ It is for this reason that vagueness doctrine has in recent years been most fully developed in the arena of freedom of expression.

In the first third of the 20th century, however, the tension between the rule of law and social mores was most pronounced in the arena of property law, and most especially in the regulation of market transactions. The preNew Deal Court strove mightily to insulate market transactions from what it viewed as unconstitutional regulation, and in the process it developed a well-articulated vagueness doctrine. In this Part, I shall carefully examine one important case in that development, Cline v. Frink Dairy Co., ${ }^{36}$ in order to demonstrate how vagueness doctrine served a function that is closely analogous to that which we have identified in the politically quite dissimilar decision of Papachristou v. City of Jacksonville.

Cline involved a bill in equity to enjoin the enforcement of a Colorado antitrust statute that prohibited combinations in restraint of trade except where the purpose of combining was "to obtain only a reasonable profit in such products or merchandise as can not yield a reasonable profit except by marketing them under the combinations previously condemned." 37 The "line between lawfulness and criminality" thus was dependent upon:

first[,] what commodities need to be handled according to the trust methods condemned in the first part of the Act to enable those engaged in dealing in them to secure a reasonable profit therefrom; second, ... what generally would be a reasonable profit for such a business; and third, what would be a reasonable profit for the defendant under the circumstances of his particular business. It would, therefore, be a complete defense for the defendant to prove in this case that it is impossible to sell milk or milk products, except by trust methods and make a reasonable profit, if he also showed that by such methods he had in fact only made a reasonable profit. ${ }^{38}$ The Court unanimously struck down the Colorado statute as vague, saying that it would be unconstitutional "[t]o compel defendants to guess on the peril of an indictment whether one or more of the restrictions of the statute will destroy all profit or reduce it below what would be reasonable." 39

\footnotetext{
35. For a full discussion, see Post, supra note 12

36. 274 U.S. 445 (1927).

37. Id. at 456.

38. Id. at $456-57$.

39. Id. at $457-58$.
} 
In reaching this conclusion the Court was required to distinguish seemingly similar contexts in which the legal standard of "reasonableness" was concededly legitimate. ${ }^{40}$ Defenders of the Colorado statute argued that negligence law commonly imposes upon members of the general public a duty to act in a "reasonable" way. The Court, however, would not accept the analogy:

It is true that, on an issue like negligence, i.e., a rule of conduct for the average man in the avoidance of injury to his neighbors, every one may be held to observe it either on the civil or criminal side of the court. It is a standard of human conduct which all are reasonably charged with knowing and which must be enforced against every one in order that society can safely exist. ... "The criterion in such cases is to examine whether common social duty would, under the circumstances, have suggested a more circumspect conduct." . . .

But it will not do to hold an average man to the peril of an indictment for the unwise exercise of his economic or business knowledge involving so many factors of varying effect that neither the person to decide in advance nor the jury to try him after the fact can safely and certainly judge the result. ${ }^{41}$

One important theme of this passage is that judgments of reasonableness in the area of negligence are acceptable because they depend upon standards of human conduct "which all are reasonably charged with knowing" in that they involve "common social duty," whereas judgments of reasonableness in the area of market price transactions are vague because they have no such ascertainable referents.

We must ask, however, whether this asserted absence of referents rests on descriptive grounds, as in Kolender, or on normative grounds, as in Papachristou. The latter conclusion is strongly suggested by Cline's concession that public utility rates must constitutionally be set so as to provide for a "reasonable" rate of return. The Court acknowledged the many cases in which it had condemned public utility commissions for "taking" property by imposing unreasonably low rates. ${ }^{42}$ But the Court nevertheless insisted that the standard of "reasonable profits" was inappropriate in the specific context of the Colorado statute:

On questions of confiscatory rates for public utilities, for instance, courts must examine in great detail the circumstances and reach a

40. So, for example, the Court noted that the Sherman Act's criminalization of unrcasonable restraints on trade did not turn on "the reasonableness of the prices fixed or the profit realized," but instead upon well-elaborated common law rules classifying the legality of forms of business arrangements. Id. at 460-63.

41. Id. at 464-65 (citation omitted).

42. See, e.g., Bluefield Water Works \& Improvement Co. v. Public Serv. Comm'n, 262 U.S. 679 (1923); Missouri ex rel. Southwestern Bell Tel. Co. v. Public Serv. Comm'n, 262 U.S. 276 (1923). 
conclusion as to a reasonable profit. But this does not justify in such a case holding the average member of society in advance to a rule of conduct measured by his judgment and action in respect to what is a reasonable price or a reasonable profit. ${ }^{43}$

Using our typology of legal rules, we might summarize the Court's contention in the following way. Although a decision rule which provides:

Rule 2a: Regulate rates so as to allow for a reasonable profit. would not cede unconstitutional discretion to government officials, a conduct rule which provides:

Rule 5a: Do not conspire to set prices that generate an unreasonable profit.

is unconstitutionally vague. So phrased, it is clear that the Court's contention cannot be that Rule 5a has no meaningful referents; the Court's argument must rather be that the standards which give content to Rule $2 \mathrm{a}$ are inappropriate for use with respect to the "average members of society" governed by Rule 5 .

Why might this be so? It is clear that the Court understood vagueness doctrine to apply in a different way to decision rules than to conduct rules. Thus it stated in Mahler v. Eby ${ }^{44}$ that "[t]he rule as to a definite standard of action is not so strict in cases of the delegation of legislative power to executive boards and officers." 45 The Court took pains to emphasize that it was, in contrast, extremely important to assure that criminal statutes "inform the accused sufficiently of the nature and cause of the accusation."46

We commonly explain this difference between decision rules and conduct rules in terms of the concept of fairness. It is said, as Cline itself avers, that it would be wrong "[t]o compel defendants to guess on the peril of an indictment" as to the meaning of a statutory standard. ${ }^{47}$ But if the use of the verb "guess" is meant to imply that it would be difficult or impossible for citizens to ascertain the substance of the statutory standard, the existence of Rule $2 a$ demonstrates that this claim is false. The large body of doctrine and precedents guiding the implementation of Rule 2a suggests that fairly definite legal criteria would have been readily available to citizens who wished to comply with Rule 5a. If Cline rests on the value of fairness, therefore, it is not on the simple notion that fairness prohibits punishing persons for transgressing unknowable standards.

In fact Cline appears to rest on a very different idea. The Court's decision must flow from its normative refusal to require members of the general public to internalize the bureaucratic imperatives of Rule $2 a$ as

43. Cline, 274 U.S. at 464.

44. 264 U.S. 32 (1924).

45. Id. at 41 .

46. Id.

47. Cline, 274 U.S. at 457. 
guides to ordinary market price transactions. Thus, as in Papachristou, vagueness doctrine functions to police the kinds of standards that may legally be intruded on particular social domains. This function is also apparent in the Court's repudiation of the negligence analogy, by which the Court exempted market price transactions from the requirements of "common social duty." Evidently, the Court had determined that the decisions of "average members of society" to set prices should remain unconstrained by both the bureaucratic standards of Rule $2 \mathrm{~A}$ and the community norms embodied in negligence law. The liberation of market price transactions from these requirements is entirely consistent with the pre-New Deal Court's hostility to price-fixing legislation as inimical to "the individual freedom of action contemplated by the Constitution."48

By understanding the function of vagueness doctrine in Cline in this way, we can make visible the subterranean paths through which the ideological perspective that dominated the Court during the 1920s exercised its influence. The pre-New Deal Court viewed market price transactions as expressive of the essential autonomous individuality of the mature citizen; it consequently 'regarded price regulations as paternalistic and as inconsistent with the constitutionally necessary independence of the person. It should not be surprising, therefore, that the Court would be reluctant to require individuals to internalize and apply either norms of "common social duty" or imperatives of bureaucratic social policy at precisely the moment when its constitutional theory dictated that individuals should be most freely expressing their essential autonomous personality. ${ }^{49}$

Vagueness doctrine was one vehicle through which the Court expressed this substantive political philosophy. ${ }^{50}$ The Court used vagueness doctrine to maintain spheres of citizen conduct free from the regulation of rules that would have required for their enforcement judgments imposing

48. Adkins v. Children's Hosp., 261 U.S. 525, 561 (1923) (striking down the District of Columbia's Minimum Wage Act as an unconstitutional interference with the liberty of contract), overruled by West Coast Hotel Co. v. Parrish, 300 U.S. 379 (1937).

49. Thus, 36 years later in United States v. National Dairy Products Corp., 372 U.S. 29 (1963), when the Court upheld against a vagueness attack the section of the Robinson-Patman Act "making it a crime to sell goods at 'unreasonably low prices for the purpose of destroying competition or eliminating a competitor," $i d$. at 29 (quoting $\S 3$ of the Robinson-Patman Act), the Court's reasoning was explicitly premised on its conclusion that the statute regulated "activity which is neither constitutionally protected nor socially desirable." Id. at 36. The Court's new-found ability to locate in the standard of "unreasonably low prices" "a meaningful referent in business practice or usage," id, was no doubt made possible by its altered substantive vision of the normative importance of market price transactions for defining the person.

50. See, e.g., Adkins, 261 U.S. at 555. Justice Holmes, who did not share this political philosophy, might have concurred in Cline for a different reason. Holmes had earlier written, in one of the Court's very first uses of the vagueness doctrine, that "[v]alue is the effect in exchange of the relative social desire for compared objects expressed in terms of a common denominator." International Harvester Co. v. Kentucky, 234 U.S. 216, 222 (1914). For Holmes, therefore, profit and price were determincd solely by personal preferences, and he might thus have viewed the concept of a "reasonable price" as a contradiction in terms. For Holmes, Rule 5a might have been the functional equivalent of Rule 4a. 
community or bureaucratic norms. Since the 1960s the Supreme Court has used vagueness doctrine to accomplish the identical goal in the sphere of freedom of expression. ${ }^{51}$

\section{IV}

\section{VAGUENESS AND SOCIAL ROLES}

Vagueness doctrine in Cline served matters of high constitutional policy. By pohicing the circumstances under which the law could require citizens to internalize and enact particular kinds of norms and standards, vagueness doctrine functioned as a medium through which the Court implicitly defined the nature of the autonomy it believed necessary for citizenship.

In this last Part of my Essay, I wish briefly to review two cases where vagueness doctrine serves analogous functions, only in the more humble and limited domain of organizational structure. Government officials commonly exercise control over members of state institutions, and vagueness doctrine is not infrequently used to probe the nature and reach of that control. My thesis is that because the doctrine requires courts to test the kinds of judgments that can be exercised within organizational contexts, the doctrine necessarily becomes a medium for judicial inquiry into the range of constitutionally acceptable forms of institutional structure.

Parker v. Levy ${ }^{52}$ raises these issues in a particularly clear way. It concerned the court-martial of Howard Levy, an Army captain who had agreed to serve in the military for two years if permitted first to complete his medical traiming. Levy spoke out against the Vietnam War and was subsequently convicted of violating Article 133 of the Uniform Code of Military Justice, which prohibits "conduct unbecoming an officer and a gentleman." 53 Levy challenged Article 133 as unconstitutionally vague. The Court rejected his claim in a five to three decision.

The disagreement between the majority and dissent is highly illuminating. The Court noted that Article 133 received its specific content from "the longstanding customs and usages of the services"54 and that its meaning was "'not measurable by our innate sense of right and wrong, of honor and dishonor, but must be gauged by an actual knowledge and experience of military life, its usages and duties." "'55 The dissent, however, plausibly argued that it was merely "judicial fantasy" to assume that Levy, "a draftinduced volunteer whose military indoctrination was minimal, at best," was

51. See, e.g., Smith v. Goguen, 415 U.S. 566 (1974) (striking down a Massachusetts "flagmisuse" statute as unconstitutionally vague).

52. 417 U.S. 733 (1974).

53. 10 U.S.C. $\S 933$ (1988).

54. Parker, 417 U.S. at 746-47.

55. Id. at 748-49 (quoting Swaim v. United States, 28 Ct. Cl. 173, 228 (1893), aff'd, 165 U.S. 553 (1897)). 
"so imbued with the ancient traditions of the military as to comprehend the arcane meaning of" Article $133 .{ }^{56}$ The dissenters objected that "we do a grave disservice to citizen soldiers in subjecting them to the uncertain regime of Art[ ]. 133 . . . simply because [this] provision[ ] did not offend the sensibilities of the federal judiciary in a wholly different period of our history." 57

The majority and dissent thus agreed that the judgnients required by Article 133 made sense only in the context of ancient military customs and traditions. They disagreed, however, on the question of whether it was constitutional for modern military law to serve as the vehicle for the application of these customs and traditions. At times both sides of the debate appeared to turn this disagreement on the narrow empirical question of whether Levy himself might actually have been aware of these traditional military norms. But in fact both majority and dissent were more powerfully drawn to the institutional dimensions of the question.

It is fair to characterize the Court's opinion as driven by its conclusion that the continued application of military custom was necessary for the achievement of military objectives. The Court's basic point was that, because the military needs "to maintain the discipline essential to perform its mission effectively,"58 it can constitutionally establish legal standards like Article 133 " "conditioned to meet certain overriding demands of discipline and duty." "59 Precisely because the ancient traditions applied through Article 133 were indispensable to sustain the mission of the army, these traditions could validly be used to define the role of a military officer.

The dissent objected to this functional account: "I should suppose that vague laws, with their serious capacity for arbitrary and discriminatory enforcement, can in the end only haniper the military's objectives of high morale and esprit de corps."60 The dissent's objection imagined that soldiers would respond to the ancient customs referenced by Article 133 with the incredulity of civilians. The dissent's objection no doubt sprang from its focus on the large influx of Vietnam era "citizen-soldiers." But because citizen-soldiers have been characteristic of the American military since its inception, the issue for the dissent must have been less the physical presence of these citizen-soldiers, than the perceived need for the military to alter its institutional structure to more closely approximate the civilian norms characteristic of these soldiers. The essential disagreement on the

56. Id. at 782 (Stewart, J.; dissenting).

57. Id. at 783 (Stewart, J., dissenting).

58. Id. at 744.

59. Id. (quoting Burns v. Wilson, 346 U.S. 137, 140 (1953)). The Court further noted that "[t]he fundamental necessity for obedience, and the consequent necessity for imposition of discipline, may render permissible within the military that which would be constitutionally impermissible outside it." Id. at 758.

60. Id. at 788 (Stewart, J., dissenting). 
Court, therefore, was whether it made institutional sense for soldiers to be treated more like civilians.

In this way vagueness doctrine became in Levy a medium through which the Court implicitly debated organizational structure. The general point I wish to make is that vagueness doctrine will often serve this function. This is because the doctrine requires courts to evaluate the standards which can be brought to bear in the enforcement and enactment of institutional roles, and this task necessarily requires courts to evaluate the identity of those roles.

This can plainly be seen in my last example, which is meant to drive the point home to an academic audience. San Filippo v. Bongiovanni ${ }^{61}$ concerned the dismissal of a tenured professor of chemistry, Joseph San Filippo, from Rutgers University. The relevant Rutgers regulation provided that tenured professors were subject to dismissal for " "failure to maintain standards of sound scholarship and competent teaching." "62 San Filippo was dismissed, however, for abusing visiting foreign scholars by requiring them to perform domestic work like gardening and cleaning and for submitting false expense reports for these scholars.

San Filippo argued that the charges against him, even if true, had nothing to do with sound scholarship or competent teaching, and hence that the regulation was void for vagueness as applied to him. The district court accepted this argument, noting "that it was 'unforeseeable' that Rutgers would use ethical violations, albeit segued into the 'sound scholarship and competent teaching language,' to dismiss San Filippo and, thus, that he was deprived of his right of fair warning." 63 The Third Circuit, however, reversed:

A reasonable, ordinary person using his common sense and general knowledge of employer-employee relationships would have fair notice that the conduct the University charged Dr. San Filippo with put him at risk of dismissal under a regulation stating he could be dismissed for "failure to maintain standards of sound scholarship and competent teaching." He would know that the standard did not encompass only actual teaching or research skills. Here, all of Dr. San Filippo's charged actions sprang from his role as a faculty member at the University. It is not unfair or unforeseeable for a tenured professor to be expected to behave decently toward students and coworkers, to comply with a superior's directive, and to be truthful and forthcoming in dealing with payroll, federal research funds or applications for academic positions. Such behavior is required for the purpose of maintaining sound scholarship and com-

61. 961 F.2d 1125 (3d Cir.), cert. denied, 113 S. Ct. 305 (1992).

62. Id. at 1127 (quoting Rutgers University Regulation 3.94).

63. San Filippo v. Bongiovanni, 743 F. Supp. 327, 337 (D.N.J. 1990), rev'd, 961 F.2d 1125 (3d Cir.), cert. denied, 113 S. Ct. 305 (1992). 
petent teaching. The academic community can reasonably conclude that otherwise the educational atmosphere is likely to become so tainted and disturbed that it would become impossible to "maintain standards of sound scholarship and competent teaching." . . .

... Were we to accept Dr. San Filippo's argument that [the regulations] were void for vagueness ... the University could never discharge Dr. San Filippo, or any other tenured professor, for any conduct not directly involving teaching or research . . . ${ }^{64}$

On the surface the debate between the district and circuit courts is about whether it is fair to charge San Filippo with knowledge that he could be dismissed for abusing visiting foreign scholars. But on closer inspection the issue of fairness can itself be seen to turn on the legal conception of the role of a tenured university professor. The district court understands professors as employees, chargeable only with knowledge of the explicit content of the rules by which they are governed. The circuit court, in contrast, conceives professors as professionals, chargeable with knowledge of all the complex, traditional, and unwritten mores of the "academic community." Because it is "fair" to attribute to San Filippo the knowledge appropriate to his role, the disagreement between the courts, although phrased in terms of vagueness doctrine, actually depends upon an underlying normative debate about the legal and social meaning of being a university professor.

Vagueness doctrine, of course, has nothing intrinsically to say about the role of a tenured professor, just as it has nothing intrinsically to say about the role of military officers. But because the doctrine requires courts to decide what kinds of judgments may appropriately be attributed to institutional actors, it necessarily becomes the occasion for judicial determination of the forms of social order that may be used to define the roles of those actors. In San Filippo the real difference between district and appellate courts concerned the location of the line separating the social world of professionalism from that of the employee, ${ }^{65}$ just as in Levy the real argument between majority and dissent concerned the location of the line separating military from civilian culture.

\section{ConcLusion}

The traditional account of vagueness doctrine, with its image of legal rules arrayed along a continuous spectrum of precision or clarity, renders these debates invisible. This is fundamentally because the traditional account narrowly focuses on the isolated properties of legal rules rather than on the relationship between these rules and the forms of social life that

64. San Filippo, 961 F.2d at 1137-38 (citation omitted).

65. For a relevant and illuminating discussion of the sociological differences between these two social roles, see W. Richard Scott's paper in Professionalization 265 (Howard M. Vollmer \& Donald L. Mills eds., 1966). 
sustain and vivify them. Once this relationship is thematized, however, it is immediately apparent that cases like Papachristou, Cline, and Levy do not turn on the abstract clarity of legal rules, but rather on the kinds of judgments, and hence the concomitant kinds of social order, which the state may constitutionally authorize and impose.

In these cases, therefore, vagueness doctrine serves as a vehicle for the implicit judicial resolution of independent questions of substantive constitutional law. We can, on the one hand, view this as a weakness of vagueness doctrine, because the doctrine suppresses a full and frank judicial evaluation of these substantive constitutional issues. Thus we might criticize Papachristou for using vagueness doctrine to evade a complete and explicit analysis of the kinds of judgments that can constitutionally be exercised by the police in dealing with the public.

But, on the other hand, we might also reflect that courts are often neither equipped nor prepared to offer comprehensive and candid constitutional analyses of social relationships, and that in such circumstances vagueness doctrine offers a useful means of exercising discriminating, indirect, and yet effective judicial control. Thus even if the Court in Papachristou were intellectually or politically unwilling to offer a fullblown constitutional assessment of transactions between the police and the public, it could nevertheless deploy vagueness doctrine strongly to influence legislative regulation of these transactions.

In the context of cases like Papachristou, Cline, and Levy, therefore, we may conclude that the value of vagueness doctrine lies essentially in the value of judicial and constitutional indirection. 
